\title{
THE EFFECTS OF SHORT TERM AND LONG TERM NAAD YOGA MED- ITATION TRAINING ON MINDFULNESS IN UNIVERSITY STUDENTS
}

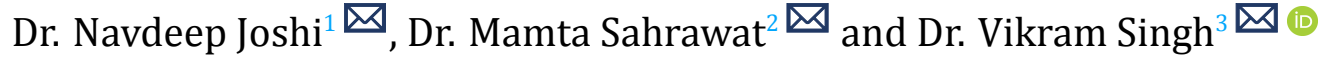 \\ ${ }^{1}$ Assistant Professor, Yoga, SLBSNSU, New Delhi, India \\ ${ }^{2}$ Assistant Professor, Physical Education, BNC (Delhi University), India. Tel.: 8851001908 \\ ${ }^{3}$ Assistant Director, PE, JNU, New Delhi, India. Tel.: 9868614409
}

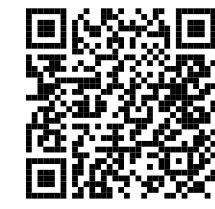

Received 6 June 2021

Accepted 18 June 2021

Published 30 June 2021

Corresponding Author

Dr. Navdeep Joshi, navyoga.yoga@ gmail.com

DOI $10.29121 /$

granthaalayah.v9.i6.2021.4041

Funding: This research received no specific grant from any funding agency in the public, commercial, or not-for-profit sectors.

Copyright: (C) 2021 The Author(s). This is an open access article distributed under the terms of the Creative Commons Attribution License, which permits unrestricted use, distribution, and reproduction in any medium, provided the original author and source are credited.

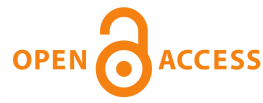

\section{ABSTRACT}

Introduction: Meditation has been practiced since times immemorial consciously or unconsciously by the people from different origins and the trend has caught more attention of the researchers worldwide due to popularity of yoga in the recent years.

Method: Internet-delivered online NAAD yoga meditation training for 6 weeks was being imparted to the university level participants $(n=67)$ and were assessed before, during and after treatment, and their compliance with the intervention they received was tracked online. In the randomized controlled trail (RCT) study, the treatments were received at a time, place, and computer of the participants' choosing with the proviso that the training be completed live and online during each of 6 successive weeks ( 6 days a week with a 32 minutes session each day). The trait MAAS, a 15-item scale designed to assess individual differences in the frequency of mindful states over time questionnaire was being used as tool to assess dispositional (also known as trait) mindfulness amongst all the participants.

Results: Both a short term (3 weeks) as well as long-term ( 6 weeks) NAAD yoga meditation programs elicited a statistically significant improvement on MAAS scores $(\mathrm{p}<.000)$.

Keywords: MAAS, Mindfulness, Online, RCT

\section{INTRODUCTION}

Due to uncertainty regarding jobs, career choice and goals besides environmental stressors, the students at the schools and colleges often undergo stress, tension and anxiety, more than anyone else perhaps.

Cost of treating psycho-somatic diseases requiring medical interventions pose double whammy for those who belong to middle and lower middle class. Even the otherwise well-off western countries have realized the importance of cost-effective 
measures to tackle stress related disorders in order to overcome economic hardships. Due to many inherent benefits, mindfulness-based interventions like asana, meditation, naturopathy have received increased attention in the popular and professional literatures for prevention, promotion and the treatment of physical and psychological ailments. There is no shortage of evidence-based literature these days which suggests that they benefit healthy young adults as well as those experiencing distress by enhancing coping, reducing negative effects, and supporting physical vitality (Baer (2003) ; Baer et al. (2008) ; Grossman et al. (2004) ; Grossman et al. (2004) ). Intervention of mindfulness training not only improves attention and performance (Mrazek et al. (2013) ), but it can also imrove one's coping skills. In yoga literature, it is often stated that the five "Kleshas" (conflicts) will always be there and "avidya", which means ignorance will always be at the core of these conflicts. Mindfulness has been described as "the awareness or being present at the moment without being judgmental to the unfolding of the experiences moment by moment" (KabatZinn (2003) ). We are most of the time by virtue of our disposition tend to stay either in the past or worry about our future, that keeps our brain cells active all the time with hyperactive amygdala region of the brain. In naad yoga meditation, the practitioners are first made to practice few asana's (annamaya kosh), mindfully. They are then instructed to observe their breath and thoughts, feelings, and sensations without being reactive; refrain from elaborating mentally beyond their simple experience of the moment; and refocus on their immediate, subjective experience when their attention strays (Bishop et al. (2004) ; Kabat-Zinn (2003) ). Meditation and relaxation appear to have similar effects on stress and self-reported spiritual experiences; however, mindfulness decreases rumination and increases positive states of mind more effectively than does relaxation (Jain et al. (2007) ; Zautra et al. (2012) ).

\section{PROCEDURE}

Participants: Undergraduate and post graduate students $(n=67)$ from across Indian universities were recruited after advertising on the social media and contacting them through e-mails. The workshop was being conducted online for 6 weeks.

Table 1 Descriptive Statistics showing the mean age of students who volunteered to undergo NAAD yoga training

\begin{tabular}{cccccc}
\hline & N & Minimum & Maximum & Mean & Std. Deviation \\
Age & 67 & 17 & 28 & 23.51 & 3.183 \\
Valid N (listwise) & 67 & & & & \\
\hline
\end{tabular}

Measure: The Mindful Attention Awareness Scale (MAAS)

The trait MAAS is a 15-item scale designed to assess individual differences in the frequency of mindful states over time. The scale is a 15 item (1-6 Likert scale) questionnaire to assess dispositional (also known as trait) mindfulness. The measurements from the MAAS tap consciousness related to self-regulation and various other 
related areas of well-being. As a trait, it has been seen that some individuals are more proficient at putting themselves into a state of mindfulness than others. This scale is based around the understanding that all humans already have varied kind of personal internal and external experience, which is awareness. Better consciousness can be built through harnessing the focusing of that awareness, which initially starts from being attentive. As one progresses, the attention enhances to become awareness of current experience or the present moment. This scale intentionally excludes mood, attitude, and motivation to keep dispositional mindfulness neutral as a construct. Those scoring higher in mindfulness scale tend to report higher levels of pleasant affect, better self-esteem, optimism, self-actualization and resilience under trying conditions. Also, lower levels of neuroticism, anxiety, depression, and emotional conflicts are reported in those scoring higher in mindfulness.

Method: Participants were given a google form URL with all instructions and assessments were completed online. Assignment to training occurred in the order that they registered online. They were then given an introduction about what is the history and origin of NAAD and its effects on the humans. 100 persons registered initially but 67 remained after implementing the inclusion and exclusion criteria.

Participants were demonstrated warming up exercises (each day 4 to5 different yogic postures) for about 10 minutes. To track participant compliance in the mindfulness and relaxation conditions, users were required to keep their camera's on at all times. In the sitting position, they were then given training in selected pranayamas (bhastrika-kapalbhati kriya) followed by OM recitation- 10 minutes). Focusing on instructions being imparted and natures' music- 15 minutes (in lying down or sitting position as deemed confortable). Lastly, they were brought back to the starting stage with backward counting (7 minutes).

Total $=30$ to 32 minutes program each day except Sundays (6 days per week) for 6 weeks.

The participants filled up the MAAS questionnaire on first day- after 3 weeks and upon completion of the 6 weeks of intervention. The subjects acted as their own controls. Repeated measures method using SPSS-25 version was being used to analyze the results.

\section{RESULTS AND DISCUSSION}

\begin{tabular}{|c|c|c|c|}
\hline & Mean & Std. Deviation & $\mathbf{N}$ \\
\hline pre intervention & 4.07 & 1.03 & 67 \\
\hline post 3 weeks training & 4.18 & 1.00 & 67 \\
\hline post 6 weeks training & 5.39 & .62 & 67 \\
\hline
\end{tabular}


Table 2 shows mean values of the participants on days-1 (4.07 \pm 1.03 ), after 3 weeks $(4.18 \pm 1.00)$, and on the last day $(5.39 \pm .624)$, which was statistically even more significantly different to pre-training $(\mathrm{p}<.000)$. Therefore, we can conclude that both a short term ( 3 weeks) as well as long-term ( 6 weeks) NAAD yoga meditation programs elicits a statistically significant improvement in MAAS scores. The Tests of Within-Subjects Effects table tells us if there was an overall significant difference between the means at the different time points.

\section{Table 3 Tests of Within-Subjects Effects}

\begin{tabular}{|c|c|c|c|c|c|c|c|}
\hline $\begin{array}{l}\text { Measure: } \\
\text { MAAS }\end{array}$ & & & & & & & \\
\hline Source & & $\begin{array}{l}\text { Type III Sum of } \\
\text { Squares }\end{array}$ & df & $\begin{array}{l}\text { Mean } \\
\text { Square }\end{array}$ & $\mathbf{F}$ & Sig. & $\begin{array}{c}\text { Partial Eta } \\
\text { Squared }\end{array}$ \\
\hline \multirow[t]{4}{*}{ time } & $\begin{array}{l}\text { Sphericity } \\
\text { Assumed }\end{array}$ & 71.587 & 2 & 35.793 & 137.78 & .000 & .676 \\
\hline & $\begin{array}{l}\text { Greenhouse- } \\
\text { Geisser }\end{array}$ & 71.587 & 1.052 & 68.068 & 137.78 & .000 & .676 \\
\hline & Huynh-Feldt & 71.587 & 1.054 & 67.911 & 137.78 & .000 & .676 \\
\hline & $\begin{array}{l}\text { Lower- } \\
\text { bound }\end{array}$ & 71.587 & 1.000 & 71.587 & 137.78 & .000 & .676 \\
\hline \multirow[t]{4}{*}{ Error(time) } & $\begin{array}{l}\text { Sphericity } \\
\text { Assumed }\end{array}$ & 34.291 & 132 & .260 & & & \\
\hline & $\begin{array}{l}\text { Greenhouse- } \\
\text { Geisser }\end{array}$ & 34.291 & $69.41:$ & .494 & & & \\
\hline & Huynh-Feldt & 34.291 & $69.57 i$ & .493 & & & \\
\hline & $\begin{array}{l}\text { Lower- } \\
\text { bound }\end{array}$ & 34.291 & 66.001 & .520 & & & \\
\hline
\end{tabular}

From Table 3 we are able to discover the F value for the "time" factor, its associated significance level and effect size ("Partial Eta Squared"). As our data violated the assumption of sphericity, we look at the values in the "Greenhouse-Geisser" row (as indicated in bold text). It has been reported when using an ANOVA with repeated measures with a Greenhouse-Geisser correction, the mean scores for MAAS were statistically significantly different $(F(1.052,69.412)=137.781, p<0.000)$.

The results presented in the previous table informed us that we have an overall significant difference in means, but we do not know where those differences occurred. This table presents the results of the Bonferroni post hoc test, which allows us to discover which specific means differed. Remember, if your overall ANOVA result was not significant, you should not examine the Pair wise Comparisons table.

Looking at the Table 4 above, we need to remember the labels associated with the time points in our experiment from the Within-Subject Factors table. This table gives us the significance level for differences between the individual time points. We can see that there was a significant difference in MAAS score between post-training (after 3 weeks) and pre-training ( $p=0.000$ ), and between post-training ( 6 weeks) and after 3 weeks of training c, and also between pre-training and 6 weeks of training 
$(\mathrm{p}=0.000)$ on NAAD Yoga meditation. From the "Mean Difference (I-J)" column we can see that mindfulness was significantly higher at this time point.

\section{Table 4 Pair wise Comparisons}

\begin{tabular}{ccccccc}
\hline $\begin{array}{c}\text { Measure: } \\
\text { MAAS } \\
\text { (I) time }\end{array}$ & $\begin{array}{c}\text { (J) } \\
\text { time }\end{array}$ & $\begin{array}{c}\text { Mean Difference } \\
\text { (I-J) }\end{array}$ & $\begin{array}{c}\text { Std. } \\
\text { Error }\end{array}$ & $\begin{array}{c}\text { Sig. }{ }^{b} \\
\text { 95\% Confidence Interval } \\
\text { for Difference }\end{array}$ \\
\hline 1 & & & & & $\begin{array}{c}\text { Lower } \\
\text { Bound }\end{array}$ & $\begin{array}{c}\text { Upper }_{\text {Bound }} \\
\text { Bound }\end{array}$ \\
\hline & 2 & $-.111^{*}$ & .020 & .000 & -.160 & -.063 \\
\hline 2 & 3 & $-1.318^{*}$ & .108 & .000 & -1.582 & -1.054 \\
\hline 3 & 1 & $.111^{*}$ & .020 & .000 & .063 & .160 \\
& 3 & $-1.207^{*}$ & .106 & .000 & -1.468 & -.945 \\
& 1 & $1.318^{*}$ & .108 & .000 & 1.054 & 1.582 \\
\hline
\end{tabular}

Based on estimated marginal means

*. The mean difference is significant at the .05 level.

b. Adjustment for multiple comparisons: Bonferroni.

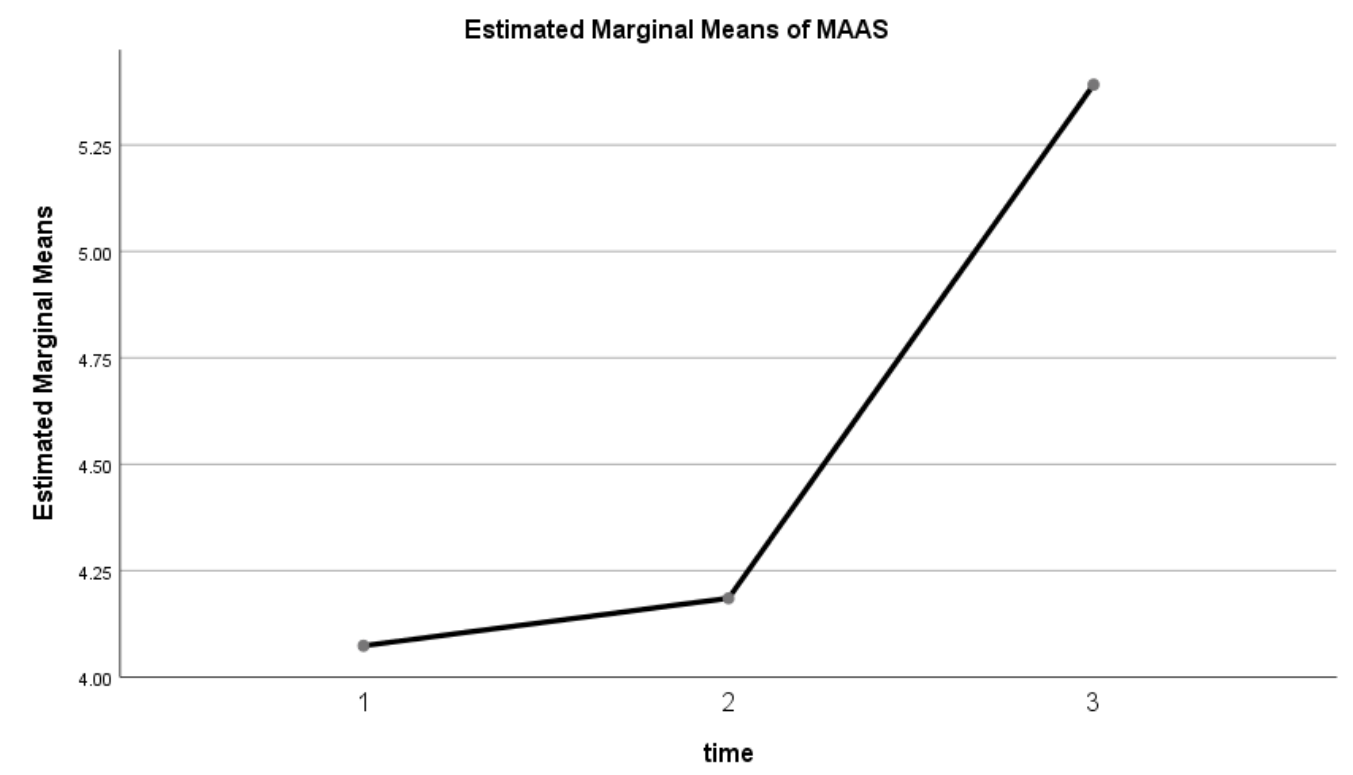

Figure 1 Profile Plot

This plot (Figure 1 ) is the last element to this analysis. It shows that the MAAS scores that represent the mindfulness were higher after 3 weeks of NAAD yoga meditation but even higher after 6 weeks of training, so the profile plot can be useful in gaining an easy understanding of the tabular results.

As per the student's witnesses, this study has additionally shown that meditation when taught online is equally effective in reducing stress and aiding coping for the 
university students. Though, the primary goal was to determine whether short trem or long term NAAD YOGA mediation could improve mindfulness as measured by the the Mindful Attention Awareness Scale (MAAS) or not.. It did indeed do so in both long term and short-term training with large effect sizes, suggesting clinically meaningful change.

Supporting research studies have suggested that the effects of brief mindfulness training has been equally effective those of prolonged training (Carmody and Baer (2009) ; Vettese et al. (2009) ). Our findings derive from a "traditional" version of NAAD YOGA meditation only and thus provide a non-confounded test of its effects. Some previous studies in which small group samples were being used had violated an ANOVA's independence-of-observation assumption but for our present study.

Our findings thus have important implications that can be easily generalized. Online mindfulness training is even more convenient and cost-effective wellness intervention. Such training is not only very simple to learn in progression but it can be provided universally, to a large community in need. In addition, NAAD yoga meditation can be an additional ingredient employed by biomedical scientists, therapists as a holistic approach in addressing complex problems to improve quality of life for chronically ill patients.

\section{CONCLUSION}

A repeated measures ANOVA with a Greenhouse-Geisser correction determined that mean MAAS scores differed statistically significantly between time points ( $\mathrm{F}$ $(1.052,69.412)=137.781, \mathrm{p}<0.000)$. Post hoc tests using the Bonferroni correction revealed that NAAD yoga meditation training elicited a slight but significant improvement in mindfulness from pre-training to 3-weeks of training (4.07 \pm 1.03 vs $4.18 \pm 1.00$, respectively), which was statistically significant $(\mathrm{p}=.000)$. However, post-training MAAS scores had risen to $5.39 \pm .624$, which was statistically even more significantly different to pre-training $(\mathrm{p}<.000)$. Therefore, we can conclude that both a short term ( 3 weeks) as well as long-term ( 6 weeks) NAAD yoga meditation programs elicits a statistically significant improvement in MAAS scores.

\section{REFERENCES}

Baer, R. A. (2003). Mindfulness Training as a Clinical Intervention: A Conceptual and Empirical Review. Clinical Psychology: Science and Practice, 10(2), 125-143. Retrieved from https://dx.doi.org/10.1093/clipsy/bpg015 10.1093/clipsy/bpg015

Baer, R. A., Smith, G. T., Lykins, E., Button, D., Krietemeyer, J., Sauer, S., Walsh, E., Duggan, D., \& Williams, J. M. G. (2008). Construct Validity of the Five Facet Mindfulness Questionnaire in Meditating and Nonmeditating Samples. Assessment, 15(3), 329-342. Retrieved from https://dx.doi.org/10.1177/1073191107313003 10.1177/1073191107313003

Bishop, S. R., Lau, M., Shapiro, S., Carlson, L., Anderson, N. D., Carmody, J., Segal, Z. V., Abbey, S., Speca, M., Velting, D., \& Devins, G. (2004). Mindfulness: A proposed operational definition. Clinical Psychology: Science and Practice, 11(3), 230-241. Retrieved from https:// 
dx.doi.org/10.1093/clipsy.bph077 10.1093/clipsy.bph077

Brown, K. W., \& Ryan, R. M. (2003). The benefits of being present: Mindfulness and its role in psychological well-being. Journal of Personality and Social Psychology, 84(4), 822848. Retrieved from https://dx.doi.org/10.1037/0022-3514.84.4.822 10.1037/0022 $-3514.84 .4 .822$

Carlson, L. E., \& Brown, K. W. (2005). Validation of the Mindful Attention Awareness Scale in a cancer population. Journal of Psychosomatic Research, 58(1), 29-33. Retrieved from https://dx.doi.org/10.1016/j.jpsychores.2004.04.366 10.1016/j.jpsychores.2004.04 .366

Carmody, J., \& Baer, R. A. (2009). How long does a mindfulness-based stress reduction program need to be? A review of class contact hours and effect sizes for psychological distress.Journal of Clinical Psychology, 65(6), 627-638. Retrieved from https://dx.doi.org/ 10.1002/jclp.20555 10.1002/jclp.20555

Grossman, P., Niemann, L., Schmidt, S., \& Walach, H. (2004). Mindfulness-based stress reduction and health benefits. Journal of Psychosomatic Research, 57(1), 35-43. Retrieved from https://dx.doi.org/10.1016/s0022-3999(03)00573-7 10.1016/s0022 -3999(03)00573-7

Jain, S., Shapiro, S. L., Swanick, S., Roesch, S. C., Mills, P. J., Bell, I., \& Schwartz, G. E. R. (2007). A randomized controlled trial of mindfulness meditation versus relaxation training: Effects on distress, positive states of mind, rumination, and distraction. Annals of Behavioral Medicine, 33(1), 11-21. Retrieved from https://dx.doi.org/10.1207/ s15324796abm3301_2 10.1207/s15324796abm3301_2

Kabat-Zinn, J. (2003). Mindfulness-Based Interventions In Context: Past, Present, And Future. Clinical Psychology: Science And Practice, 10, 144-156.

Mrazek, M. D., Franklin, M. S., Phillips, D. T., Baird, B., \& Schooler, J. W. (2013). Mindfulness Training Improves Working Memory Capacity and GRE Performance While Reducing Mind Wandering. Psychological Science, 24(5), 776-781. Retrieved from https://dx.doi .org/10.1177/095679761245965910.1177/0956797612459659

Segal, Z., Williams, J. M. G., \& Teasdale, J. D. (2002). Mindfulness- Based Cognitive Therapy For Depression: A New Approach For Preventing Relapse. New York, NY: Guilford Press.

Vettese, L. C., Toneatto, T., Stea, J. N., Nguyen, L., \& Wang, J. J. (2009). Do Mindfulness Meditation Participants Do Their Homework? And Does It Make a Difference? A Review of the Empirical Evidence. Journal of Cognitive Psychotherapy, 23(3), 198-225. Retrieved from https://dx.doi.org/10.1891/0889-8391.23.3.198 10.1891/0889-8391.23.3.198

Zautra, A. J., Davis, M. C., Reich, J. W., Sturgeon, J. A., Arewasikporn, A., \& Tennen, H. (2012). Phone-based interventions with automated mindfulness and mastery messages improve the daily functioning for depressed middle-aged community residents. Journal of Psychotherapy Integration, 22(3), 206-228. Retrieved from https://dx.doi .org/10.1037/a0029573 10.1037/a0029573 